
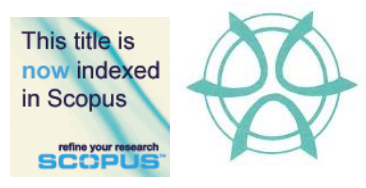

PLANNING MALAYSIA:

Journal of the Malaysian Institute of Planners

VOLUME 15 ISSUE 1 (2017), Page 55 - 64

\title{
RENEWABLE ENERGY AND TRADE DISPUTES: IMPLICATIONS ON SOLAR PHOTOVOLTAIC MANUFACTURING IN MALAYSIA
}

\author{
Hui Nee Au Yong ${ }^{1}, \&$ Kock Lim Tan ${ }^{2}$ \\ ${ }^{I}$ Faculty of Business and Finance \\ UNIVERSITI TUNKU ABDUL RAHMAN
}

\begin{abstract}
Malaysia has realised the importance of renewable energy (RE) in the energy mix and continuously reviewing its energy policy to ensure sustainable energy supply. The use of RE is among the options although the RE capacity is still underutilized. Malaysia achieves 5.5\% share of RE in the energy mix by 2015, and the RE sector is expected to double by 2020 with strong growth in the solar photovoltaic (PV), biomass and biogas markets. Beyond 2020, it is predicted that solar energy will surpass all other forms of RE for Malaysia and other countries, and the solar power will be the long term source of energy supply. After an investigation on the RE policy, the domestic solar PV manufacturing scenario is elaborated in this paper. This includes the solar PV manufacturing, issues and trade disputes, and the way forward. Among the key findings from this paper include: the foreign direct investment (FDI) related to RE sector especially from the US and lately China, have increased rapidly, and more 'green' jobs in the solar PV manufacturing and installation sectors have been created. With the existence of trade disputes between the United States and the European Union with China, Malaysia has the potential to reap benefits with the inflow of direct investments from China. Nevertheless, the future incidence of RE trade disputes is still uncertain.
\end{abstract}

Keyword: Feed-in-tariff, green technology, renewable energy, solar photovoltaic, trade disputes

Date Received: $30^{\text {th }}$ April 2016

Date of Acceptance: $30^{\text {th }}$ October 2016 
Hui Nee Au Yong, \& Kock Lim Tan

Renewable Energy and Trade Disputes: Implications on Solar Photovoltaic Manufacturing in Malaysia

\section{INTRODUCTION}

As the level of carbon dioxide keeps increasing and causing global warming, countries need to introduce the generation of electricity with an energy mix that is sustainable. Data from United Nations indicate that Malaysia recorded 187 million tons of carbon emission or 7.2 tons per capita in 2006. During the United Nations Climate Change Conference 2009 (COP 15) in Copenhagen, Denmark, the Malaysian Prime Minister declared that the country has agreed by 2020 to reduce its carbon dioxide emissions to Gross Domestic Products (GDP) intensity by 40 percent compared to 2005 levels (BERNAMA, 2009). The Malaysian Government promotes renewable energy by enacting the Renewable Energy Act 2011, the introduction of Feed-in-Tariff (FiT), the establishment of Sustainable Energy Development Authority (SEDA) and the formulation of the green technology policy (KeTTHA, 2012). Currently, about 90\% of electricity in Malaysia is mainly produced using liquid natural gas (LNG) and coal (Economic Planning Unit, 2006). Table 1 illustrates that electricity generation in Malaysia heavily relies on fossil fuels.

Table 1 Fuel Mix for Electricity Generation in Malaysia, 2000-2010.

\begin{tabular}{lllll}
\hline YEAR & GAS $(\%)$ & COAL $(\%)$ & OTHERS $(\%)$ & $\begin{array}{l}\text { TOTAL } \\
(\text { GWh })\end{array}$ \\
\hline $20005000-02$ & 77 & 9 & 14 & 69,280 \\
2005805 & 70 & 22 & 8 & 94,299 \\
2010069 & 56 & 36 & 8 & 137,909 \\
\hline
\end{tabular}

Source: EPU(2006)

This paper presents some of the key issues of the development of RE for a green economy in Malaysia, and makes reference to the solar panel global trade dispute that is building up and to solar industries that are under protectionist policies.

\section{RE SCENARIO IN MALAYSIA}

RE mix for Malaysia in 2012 was made up of 58MW (41\%) from biomass, $47 \mathrm{MW}(35 \%)$ from solar and 32MW (24\%) from other RE sources including biogas, solid waste and small hydro, contributing a total of $137 \mathrm{MW}$ of RE electricity to the power grid (SEDA, 2012). The Renewable Energy Roadmap provides long-term goals and a holistic approach that encourages various types of renewable resources in the energy mix (Table 2). 
PLANNING MALAYSIA

Journal of the Malaysia Institute of Planners (2017)

Table 2 Renewable Energy Quota

\begin{tabular}{lllll}
\hline \multicolumn{1}{c}{ Source } & $\mathbf{2 0 1 1 / 2 0 1 2}(\mathbf{M w})$ & $\mathbf{2 0 1 3}$ & $\mathbf{2 0 1 4}$ & Total \\
\hline Biogas & 30 & 30 & 20 & 80 \\
Biomass & 75 & 70 & 60 & 205 \\
Hydro & 30 & 30 & 95 & 155 \\
Solar & 54 & 52 & 52 & 158 \\
\hline TOTAL & $\mathbf{1 8 9}$ & $\mathbf{1 8 2}$ & $\mathbf{2 2 7}$ & $\mathbf{5 9 8}$ \\
\hline Source: SEDA & & & &
\end{tabular}

According to SEDA, after the launch of Feed-in-Tariff (FiT) in 2011, 400 MW (40 percent target) were connected to the power grid by 2015 (BERNAMA, 2015a). The FiT scheme has a key objective to provide financial support to residential, industrial and commercial consumers with 21 years payback period and $8 \%$ per annum degression rate (The Star Online, 2013). Furthermore, Malaysia targets to generate 2,000 megawatts (MW) of electricity from RE sources by 2020 (Table 3). Two new mechanisms were introduced as part of the efforts to achieve the target, which are net-metering and utility-scale solar (USS). The National Renewable Energy Policy and Action Plan formulated by the Ministry of Energy, Green Technology and Water aims to increase generation of RE power capacity in Malaysia to 4,000 MW by 2030. This increase will be supported by strong growth in the solar PV, biomass and biogas markets.

Table 3 Malaysian National RE Targets

\begin{tabular}{cccc}
\hline Year & $\begin{array}{c}\text { Cum. RE } \\
\text { Capacity }\end{array}$ & $\begin{array}{c}\text { RE Power Mix (vs. } \\
\text { Peak DD. })\end{array}$ & $\begin{array}{c}\text { Cumulative CO } \\
\text { Avoided }\end{array}$ \\
\hline 2010 & $73 \mathrm{MW}$ & $0.50 \%$ & 0.3 M.T. \\
2015 & $985 \mathrm{MW}$ & $5.5 \%$ & 11.1 M.T. \\
2020 & $2,080 \mathrm{MW}$ & $11 \%$ & 42.2 M.T. \\
2030 & $4,000 \mathrm{MW}$ & $17 \%$ & 145.1 M.T. \\
\hline
\end{tabular}

Source: KeTTHA, (2008)

Globally, by 2050 , it is expected that RE sources will play generate a cumulative capacity of $11.5 \mathrm{GW}$, out of which $9 \mathrm{GW}$ from solar PV, as illustrated in Figure 1. Solar power will be the long-term global source of energy supply. Solar power generation possesses advantages of low greenhouse gasses (GHG) emission, low maintenance cost and low operation noise, and therefore it is 
Hui Nee Au Yong, \& Kock Lim Tan

Renewable Energy and Trade Disputes: Implications on Solar Photovoltaic Manufacturing in Malaysia

considered the best choice for future electricity generation (Hosseini \& Wahid, 2014).

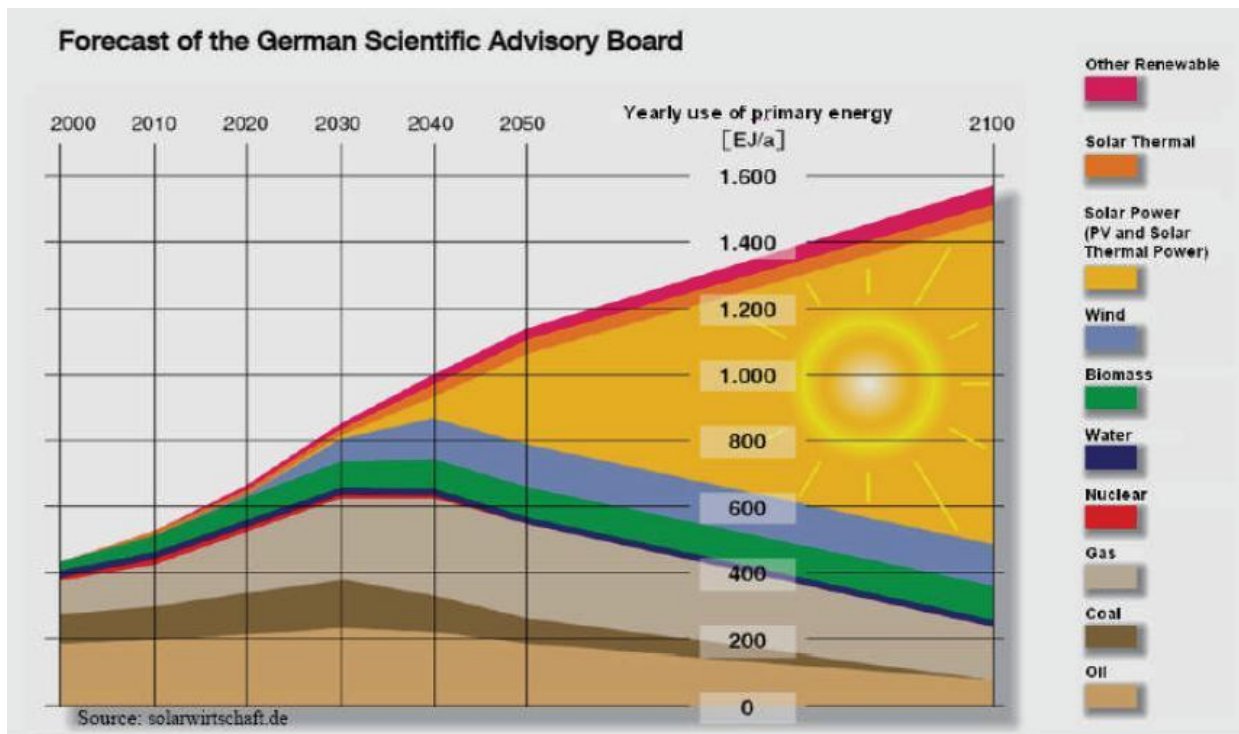

Figure 1 Long-Term Global Energy Supply

After the launch of the FiT scheme, the number of solar PV installations in Malaysia has been increasing. FiT has been successful in promoting RE at the small scale generation level. Additionally, as shown in Table 4, 10,852 jobs were created after 13 months of the e-FiT system launched. The two highest job contributions were from the biomass and the solar PV sectors, which were 4,389 and 4,224 jobs respectively (SEDA, 2012).

Table 4 Statistics of Green Job Creation in Malaysia.

\begin{tabular}{lc}
\hline RE Technology & No. of Job Created \\
\hline Biogas (Palm Oil Waste, Agro-Based, Farming) & 513 \\
Biomass (Palm Oil Waste, Agro-Based) & 4,389 \\
Small Hydro & 1,726 \\
Solar PV & 4,224 \\
\hline Total & $\mathbf{1 0 , 8 5 2}$ \\
\hline Source: SEDA (2012)
\end{tabular}

\section{SOLAR PV MANUFACTURING}

China is the world's top solar PV manufacturer. Goodrich et al. (2014) found that China's price advantage is driven by scale and supply chain development. China 
PLANNING MALAYSIA

Journal of the Malaysia Institute of Planners (2017)

is successful in attracting Incoming Foreign Direct Investments (FDIs), mainly through the establishment of joint ventures with western partners, which at the same time are potential channels for accelerating technology transfers into China (DeLaTour, Glachant \& Meniere, 2011).

PV imports in the US have been rising for reasons including increasing solar module production in places like Malaysia; Malaysia is now a large PV module supplier to the US, as Malaysia is the production base for First Solar Malaysia and AUO SunPower, and the German producer, Q-Cells (now Hanwha Q-Cells owned by Korean) (Platzer, 2012). Since the establishment of First Solar Malaysia in 2008, Malaysia has become the home to top manufacturers of solar PV around the globe. According to Sawhney and Kahn (2011), Malaysia's share in the US import of the core high-tech solar modules was zero in 1989 versus six percent in 2010 (and the fifth largest source after China, Mexico, Japan and Taiwan).

The solar PV industry is one of the growth sectors for electrical and electronics (E\&E) in Malaysia. The growth was incentivised by the award off pioneer status, favourable investment tax allowance and the Green Technology Financing Scheme (MIDA, 2015; Green Tech Malaysia, n.d.). Platzer (2012) suggests that low labor cost environment of countries such as China and Malaysia has also contributed in making them solar PV production hubs. Malaysian Government also provides additional bonus FiT rate based on bonus criteria of locally manufactured PV modules. As a result, solar PV manufacturing has grown especially in Penang, Kedah, and Sarawak (Table 5).

Table 5 Major Solar PV Industrial Players in Malaysia

\begin{tabular}{|c|c|c|c|}
\hline No. & State & Location & Company \\
\hline \multirow[t]{2}{*}{1} & Johor & Iskandar Malaysia & Xinyi Solar \\
\hline & & $\begin{array}{l}\text { Port of Tanjung } \\
\text { Pelepas }\end{array}$ & Flextronics (for Sun Edison) \\
\hline 2 & Kedah & Kulim Hi-Tech Park & First Solar, Panasonic Energy \\
\hline 3 & Melaka & Rembia & AU Optronics - SunPower \\
\hline \multirow[t]{3}{*}{4} & Penang & Prai, Penang & Jinko Solar \\
\hline & & Bayan Lepas & JA Solar \\
\hline & & $\begin{array}{l}\text { Penang Science } \\
\text { Park }\end{array}$ & TS Solar \\
\hline 5 & Perak & $\begin{array}{l}\text { Kanthan Industrial } \\
\text { Area, Ipoh }\end{array}$ & Solar Twin Creeks / TCTI \\
\hline \multirow[t]{2}{*}{6} & Sarawak & Sama Jaya, Kuching & Comtec Solar, Sun Edison \\
\hline & & Bintulu & Tokuyama \\
\hline 7 & Selangor & $\begin{array}{l}\text { Sepang, Selangor } \\
\text { Science Park } 2\end{array}$ & Hanwha Q-Cells \\
\hline
\end{tabular}


Hui Nee Au Yong, \& Kock Lim Tan

Renewable Energy and Trade Disputes: Implications on Solar Photovoltaic Manufacturing in Malaysia

The main Malaysian PV manufacturing are First Solar and Panasonic Energy in Kulim Hi-Tech Park, JA Solar, Jinko Solar and TS Solar in Penang Science Park, Solar Twin Creeks in Ipoh, Hanwha Q-Cells in Selangor Science Park 2, AUO-SunPower in Rembia, Xinyi Solar in Iskandar Malaysia, Flextronics produces solar PV panels for Sun Edison in Port of Tanjung Pelepas, Comtec Solar and Sun Edison in Kuching, and Tokuyama in Bintulu. In 2015, Malaysia has turned into a major destination for Chinese solar companies seeking to circumvent the high taxes imposed by US and Europe since 2012 (The Edge Market, 2015).

Malaysia offers an advantageous location evidenced by the announcement of global solar PV manufacturers, JA Solar, to build a 400MW solar cell plant at RM300 million (Osborne, 2015) and Jinko Solar's inauguration of its 500MW solar cell and 450MW solar module fab in Penang (Jinko Solar, 2015). These facilities seemed to be established as a solution to the US's antidumping duties that are imposed on certain China-made PV products (Energy Trend, 2015).

The Malaysian industrial eco-system, especially intellectual property (IP) protection and well-established semiconductor and supporting industries, has help to attract world major solar PV producers to set up their overseas production facilities in Malaysia. JASolar, for instance, was pleased to be able to support Malaysia's objectives of growing the renewable energy industry (BERNAMA, 2015b). It invested in Penang because of the strategic location, good infrastructure, highly skilled workforce and the support from state and federal authorities (Mok, 2015). Furthermore, locating in Malaysia is part of its longterm strategy of moving some of its manufacturing sites to outside China in order to reduce geographical risk, and to be able to adjust to politics and policies around the world (The Edge Market, 2015). As for JinkoSolar, Malaysia was chosen due to its offering of a pool of highly educated workers, advanced industry infrastructure, a receptive business investment climate and cost-competitive environment, and also to avoid single production base risks (Jinko Solar, 2015).

\section{ISSUES ON RENEWABLE ENERGY AND TRADE DISPUTES}

It was reported that the challenges faced by the Malaysian solar industry include limited local market size, human capital development, the need for more investments from public and private entities as well as the increasing global market competition (BERNAMA, 2014). In addition, the solar PV panels manufacturing involves high energy consumption and the use of chemicals which are harmful to the environment (Ismail, 2015). Environmental Impact Assessment Report 2013 on First Solar's maintenance activity of the semiconductor deposition equipment in Kulim facility has recorded cadmium (Cd) in excess of the $5 \mu \mathrm{g} / \mathrm{m} 3$ limit. 
PLANNING MALAYSIA

Journal of the Malaysia Institute of Planners (2017)

Globally, the emergence of more solar panel production countries has resulted in an increasingly globalized supply chain and higher frequency of RE trade disputes (Lewis, 2014). In 2012, the U.S. implemented anti-dumping duties which was applicable to Chinese solar cells used for panel manufacturing. However, many Chinese solar manufacturers produce panels from cells produced out of China especially Taiwan, while components of ingots and wafers are manufactured in China. The U.S. ruled in January 2015 that solar PV imports from China and Taiwan harmed American manufacturers, and imposed the antidumping duties on China PV modules, and Taiwan-made solar cells as well. In December 2015, the European Commission announced preliminary measures of anti-circumvention duties and anti-subsidy duties on Chinese solar PV panels and cells shipped from Taiwan and Malaysia to the European Union from 30 May 2016 onwards.

\section{THE WAY FORWARD}

Ahmad and Tahar (2014) suggest that availability of renewable resource and feed-in tariff rate are the most important sub-criteria from economical aspect while from technical aspect are the efficiency and maturity of technology. There are vast investment opportunities in the green technology industry. As of June 2011, the total investment in Malaysia solar energy industry has hit RM15.8 billion and generated some 14,300 jobs (Kaur, 2011). Among these investments were by Comtec Solar, JA Solar, Jinko Solar and Xinyi Solar, all from China. This is timely and in line with the aim of Malaysia to become number two in the global solar PV manufacturing by 2020, second only to China. With its existing supporting industries and the complementary development, this solar project will contribute to the overall ecosystem for the PV industry and further enhance Malaysia competitiveness as the next major player in the PV industry. Nevertheless, new investments, such as Jinko Solar must produce solar cells in the facility in Malaysia without sourcing its primary input from China/Taiwan at subsidized prices. Malaysia does not want to be used as a transhipment point for China and Taiwan solar cells and panels to enter major markets such as the United States and the European Union. 


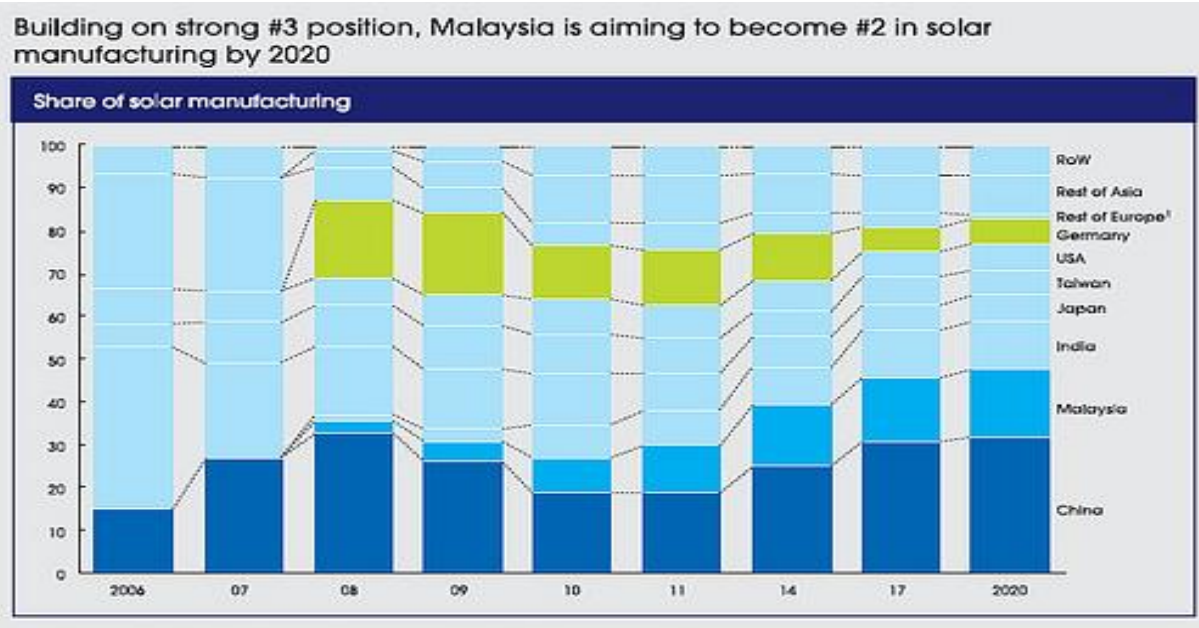

' Rest of Europe for the years 2008 and 2007 includes Germany

Figure 2 Aiming to Become No. 2 in Solar Manufacturing by 2020 Source: The Green Mechanics

\section{CONCLUSION}

It is unfortunate that the future RE trade disputes is unknown. As countries develop RE support programs, questions remain on industrial policies that possibly constitute a conflict with trade rules. When RE is subsidized, there are inherent conflicts with international trade rules. As a result, the utilization of RE technologies as an important part of climate change solution, and increasing trade tensions, will add to both the economic and political costs of deployment. Thus far, Malaysia has successfully maintained as international and reputed solar manufacturers. The country has benefited from the US-China trade disputes which have caused China and Taiwan solar producers transferring their manufacturing outside China (and to Malaysia) to avoid the anti-dumping measures imposed by the US. Additionally, the inking of the Trans-Pacific Partnership Agreement (TPPA) and negotiation of Regional Comprehensive Economic Partnership (RCEP), Malaysia could be a beneficiary of the complex interaction of global trade rules, economic competitiveness and environmental policies in the production of solar PV, where tariffs have the most immediate effect. Malaysia, with its proactive government policies, control, price regulation and right manufacturing ecosystem, is all set to become the second-largest solar manufacturer in the world. 


\section{REFERENCES}

Ahmad, S. \& Tahar, R. M. (2014). Selection of renewable energy sources for sustainable development of electricity generation system using analytic hierarchy process: a case of Malaysia. Renewable Energy, 63, 458-466.

BERNAMA (2009, December 17). Malaysia announces conditional 40 percent cut in emissions. BERNAMA. Retrieved from http://www.bernama.com/bernama/ v8/newsindex.php?id=463031

BERNAMA (2014, November 7). The Malaysian solar PV roadmap 2030 to spur solar industry development and capacity building. BERNAMA. Retrieved from http://www.bernama.com/bernama/ v8/newsindex.php?id=1083038

BERNAMA (2015a, October 6). Malaysia set to record over 2,000 megawatts of RE by 2020. BERNAMA. Retrieved from http://www.bernama.com/bernama/ v8/newsindex.php?id=1177284

BERNAMA (2015b, October 22). JA Solar to increase exports to US, emerging markets. BERNAMA. Retrieved from http://www.bernama.com/bernama/ v8/bu/newsbusiness.php?id=1182003

DeLaTour, A., Glachant, M., \& Meniere, Y. (2011). Innovation and international technology transfer: The case of the Chinese photovoltaic industry. Energy Policy, 39(2), 761-770.

Economic Planning Unit (2006). Ninth Malaysia Plan 2006-2010. Putrajaya, Malaysia: EPU.

Economic Planning Unit (2015). Eleventh Malaysia Plan 2011-2015. Putrajaya, Malaysia: EPU.

Energy Trend (2015, October 20). JA Solar's Malaysian PV cell plant to become operational. Energy Trend. Retrieved from http://pv.energytrend.com/news/ JASolar_s_Malaysian_PV_Cell_Plant_to_Become_Operational.html

Goodrich, A. C., Powell, D. M., James, T. L., Woodhouse, M., \& Buonassisi, T. (2013). Assessing the drivers of regional trends in solar photovoltaic manufacturing. Energy and Environmental Science, 6(10), 2811-2821.

Green Tech Malaysia (n.d). Green Technology Financing Scheme (GTFS). Retrieved from https://www.gtfs.my/

Hosseini, S. E., \& Wahid, M. A. (2014). The role of renewable and sustainable energy in the energy mix of Malaysia: a review. International Journal of Energy Research, 38(14), 1769-1992.

Ismail, A. M., Ramirez-Iniguez, R., Asif, M., Munir, A. B., \& Muhammad-Sukki, F. (2015). Progress of solar PV in ASEAN countries: a review. Renewable and Sustainable Energy Reviews, 48, 399-412.

Jinko Solar (2015, May 26). JinkoSolar inaugurates its first overseas solar cell and solar module fab in Penang, Malaysia. Retrieved from http://jinkosolar.com/ us/press_post/jinkosolar-inaugurates-its-first-overseas-solar-cell-and-solarmodule-fab-in-penang-malaysia/

Kaur, S. (2011, October 4). Senai Hi-Tech Parks sets to attract more solar players. New Straits Times. Retrieved from https://www.pressreader.com/malaysia/newstraits-times/20160627/282741996119378

KeTTHA [Ministry of Energy, Green Technology \& Water] (2012). National green technology policy and its implementation challenges. 
Hui Nee Au Yong, \& Kock Lim Tan

Renewable Energy and Trade Disputes: Implications on Solar Photovoltaic Manufacturing in Malaysia

KeTTHA (2008). National reewable energy policy and action plan.

Lewis, J. I. (2014). The rise of renewable energy protectionism: emerging trade conflicts and implications for low carbon development. Global Environmental Politics, 14(4), 10-35.

MIDA (2015). Incentives in green technology industry. Retrieved from http://www.mida.gov.my

Mok, O. (2015, October 21). Leading Chinese solar cell maker launches RM300m facility in Penang. Malay Mail Online. Retrieved from http://www.themalaymailonline.com /money/article/leading-chinese-solar-cellmaker-launches-rm300m-facility-in-penang

NewsBase (2015, October 3), China's new solar silk road. NewsBase. Retrieved from http://newsbase.com/commentary/china\%E2\%80\%99s-new-solar-silk-road

Osborne, M. (2015, May 18). JA Solar building 400MW solar cell plant in Malaysia. PVTech. Retrieved from https://www.pv-tech.org/news/ja_solar_building_400mw _solar_cell_plant_in_malaysia_forms_jv_in_india

Platzer, M. D. (2012). U.S. solar photovoltaic manufacturing: industry trends, global competition, federal support. CRS Report for Congress.

Sawhney, A., \& Kahn, M. E. (2011). Understanding cross-national trends in high-tech renewable power equipment exports to the United States. NBER Working Paper 17217

SEDA (2012). Annual report 2012.

The Edge Market (2015) JA Solar to begin exporting solar cells from Malaysia next month. 21 Oct. 2015

The Star Online (2013, June 17). Bank offering loans to buy solar panels. The Star Online. Retrieved from http://www.thestar.com.my/ news/nation/2013/06/17/bankoffering-loans-to-buy-solar-panels/ 